\title{
Analysis of Sedimentation for The Optimization of Lempake Dam Operations for Flood Control for The City of Samarinda, Province of East Kalimantan
}

\author{
Sandi Erryanto ${ }^{1,2^{*}}$, Ussy Andawayanti ${ }^{2}$, Ery Suhartanto ${ }^{2}$ \\ ${ }^{1}$ River Basin Organization of Kalimantan III, Directorate General of Water Resources, \\ The Minister for Public Works and Housing, Samarinda, East Kalimantan Province, \\ 75123, Indonesian \\ ${ }^{2}$ Water Resources Engineering Department, Faculty of Engineering, Universitas \\ Brawijaya, Malang, 65145, Indonesia \\ axlsandyrose2000@yahoo.com
}

Received 10-11-2020; accepted 07-12-2020

\begin{abstract}
The Lempake Dam currently functions as a dam that provides raw water for irrigation and clean water, besides its indirect functioning as the only flood control dam in the Karangmumus sub-watershed. Current conditions indicate that the Lempake Reservoir has experienced decreased capacity from year to year. At the normal water level, the reservoir capacity of Lempake Reservoir in 2013 was 0.76 million $\mathrm{m}^{3}$ and in 2018 was 0.39 million $\mathrm{m}^{3}$. Therefore, efforts are needed to control reservoir sedimentation and reservoir operations to allow the Lempake Dam to continue to function as a flood control reservoir. This study was carried out by analyzing the volume of sedimentation in the reservoir using the ArcGIS program and analyzing the flood hydrograph at the site by flood routing at the Pasar Segiri River, optimizing reservoir operations, and mapping flood inundation using the RAS Mapping program (HECRAS). The results showed that the storage volume in 2020 is predicted to be 0.241 million $\mathrm{m}^{3}$ with an annual sediment rate of 0.074 million $\mathrm{m}^{3}$. From the flood routing analysis and optimization of reservoir operations, the cross-sectional capacity of the river in Pasar Segiri (safe limit elevation $+3.30 \mathrm{~m}$ ) is insufficient for a flood discharge of a return period of more than 2 years (more than $222.14 \mathrm{~m}^{3} / \mathrm{sec}$ ) for Scenario 1, and of more than 5 years (more than 320.48 $\mathrm{m}^{3} / \mathrm{sec}$ ) for Scenario 2.
\end{abstract}

Keywords: ArcGIS, flood control, reservoir operations, sedimentation

\section{Introduction}

The Karangmumus River that runs through the City of Samarinda flows from the north up to its confluence with the Mahakam River; this river is a sub-drain of the Mahakam River, in accordance to

Cite this as: Erryanto, S., Andawayanti, U., \& Suhartanto, E. (2021). Analysis of Sedimentation for The Optimization of Lempake Dam Operations for Flood Control for The City of Samarinda, Province of East Kalimantan. Civil and Environmental Science Journal (Civense), 4(1), 10-21. doi: https://doi.org/10.21776/ub.civense.2021.00401.2 
its function as the primary sub-drain of the Karangmumus River, allowing outflow discharge to flow from the spillway of the Lempake Dam. The Lempake Dam at present functions to supply raw water for irrigation and clean water, and additionally, the Lempake Dam indirectly functions as the sole flood control dam in the Karangmumus sub-watershed. The cross-section of the Karangmumus River in the back of Pasar Segiri is one of the most critical river cross-section points in terms of dimensional sufficiency to allow the flood discharge of the Karangmumus River to flow. The most detrimental hydraulic effect is the narrowing in the back part of Pasar Segiri, which causes the flow to be impeded and sediment to build up downstream of the bridge [6].

The water-filled area of Lempake Reservoir is at present covered by almost $90 \%$ by water plants, and extremely serious sedimentation is occurring in the reservoir [6]. In several locations of the reservoir water area, reclamation has been performed by residents, and particularly on the right side of the reservoir water area, reclamation has been performed for roads.

Often, the Karangmumus River possesses a discharge amount that exceeds the capacity of the river flow, and this occurrence recurs almost every year, which causes flooding to occur in several parts of the City of Samarinda [6]. In addition to the size of the discharge flow amount from the upstream that cannot be contained by the river flow, another issue is the narrowing of the river body due to settlements constructed at the river shallows, and riverbed silting due to sedimentation [6].

To conduct analysis of the containment volume of the reservoir and of the spatial distribution of sedimentation, the geographical information system (GIS) software that may be utilized for this purpose is ArcGIS version 10.4 from the Environmental System Research Institute (ESRI) [11]. Primary data from bathymetry measurements can be processed with the interpolation method in ArcGIS. Bathymetry data is developed in the ArcGIS software, and this allows the reservoir volume at each increase of the water surface elevation to be found through Surface Volume (3D Analyst) as part of ArcGIS. The volume of the reservoir will become the containment capacity [2].

The aim of this study among others is to find out the amount of sedimentation in Lempake Reservoir and its spatial distribution, to find out the flood hydrograph at the dam spillway and the river part close to Pasar Segiri with floods of various return periods, and to find out the technical conditions of the river cross-section close to Pasar Segiri during times of floods.

\section{Material and Methods}

The Lempake Dam is located in Karangmumus River, Lempake Sub-District, North Samarinda Regency, City of Samarinda, East Kalimantan, at the coordinate position of 0 24'29.62" South Latitude and $117^{\circ} 11^{\prime} 34.48^{\prime \prime}$ East Longitude. The overall area of the Karangmumus Watershed is $\pm 321.6 \mathrm{~km}^{2}$, while the area of Lempake Dam sub-watershed is $\pm 194.5 \mathrm{~km}^{2}$ (Figure 1).

\subsection{Stages of Conducting the Study}

1. Collection of data and survey results at the study location (daily rainfall data, AWLR discharge data, and digital mapping (land usage and soil types)).

2. Conducting a quality test for rainfall data with usage of the RAPS (Rescaled Adjusted Partial Sums) method [3]. Quality testing for rainfall data was performed by testing data consistency, data homogeneity, and inliers and outliers in the data [10].

3. Conducting analysis of the regional maximum daily rainfall with usage of the method of Thiessen polygons [9].

4. Conducting analyses of frequency, goodness of fit testing, and planned rainfall. Frequency analysis was performed with usage of the Gumbel Type I and Log Pearson Type III methods, after which the planned rainfall was selected based on the goodness of fit testing [8].

5. Conducting analysis of effective rainfall. Analysis of effective rainfall was performed by the hourly distribution of rainfall by the PSA 007 method and the rate of infiltration by the Horton method [5]. 
6. Conducting analysis of the flood hydrograph. Analysis of the flood hydrograph was performed by considering the amount of flood discharge for various flood return periods $\left(\mathrm{Q}_{1.01 \mathrm{yr}}, \mathrm{Q}_{2 \mathrm{yr}}, \mathrm{Q}_{5 \mathrm{yr}}, \mathrm{Q}_{10 \mathrm{yr}}\right.$, $\mathrm{Q}_{25 \mathrm{yr}}$, and $\mathrm{Q}_{50 \mathrm{yr}}$ ) with the Nakayasu method [4].

7. Conducting analysis of the distribution of reservoir sedimentation with the spatial method. The spatial method utilized in this study is the Kriging Spatial Interpolation method in ArcGIS with analysis of bathymetry data from 2013 and 2018, which is then interpolated to the current conditions in 2020 based on the analysis of the sedimentation rate of the reservoir [2].

8. Conducting analysis of the reservoir volume. Bathymetry data was developed in the ArcGIS software in order to find out the reservoir volume for each increase in the water surface elevation with usage of Surface Volume (3D Analyst) as part of ArcGIS ${ }^{[2]}$. The reservoir volume became the containment capacity.

9. Conducting analysis of simulated dam operations. Dam operations were simulated to optimize the containment capacity of the dam in reducing floods.

10. Conducting flood routing analysis for the dam and the river downstream of the dam. Flood routing for the dam was conducted on the primary and emergency dam spillways. The outflow that resulted from the spillways became the input for flood routing analysis along the river from Lempake Dam to Pasar Segiri with the Muskingum method. Flood routing downstream of the dam was conducted at Pasar Segiri for observations, with the remaining basin as its watershed [9].

11. Conducting mapping of flood inundation. The mapping of flood inundation was performed through RAS Mapping with the HEC-RAS software. The resulting inundation was then overlaid on aerial photography for greater clarity in understanding the resulting flood inundation map. The input from inundation mapping with HEC-RAS utilized hydrograph data as the results of flood hydrograph analysis for Lempake Dam [1].

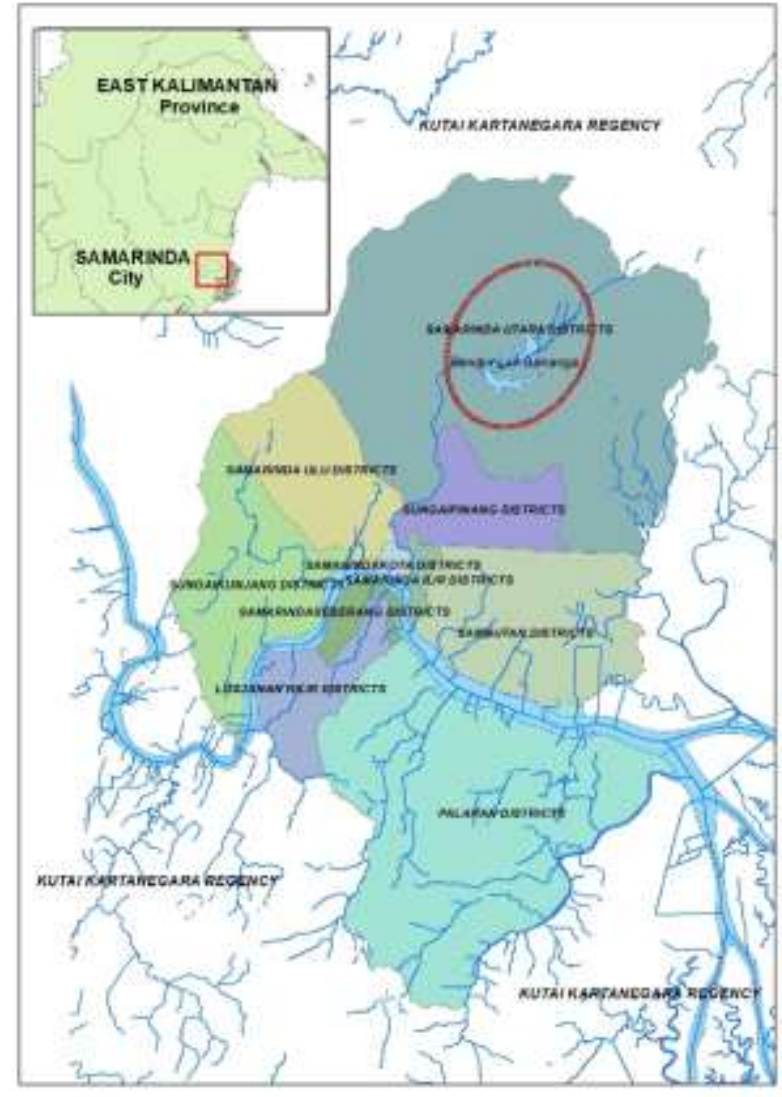

Figure 1. Study Location 


\section{Results and Discussion}

\subsection{Consistency Testing of Rainfall Data}

In this study, consistency testing of the data was performed with the Rescaled Adjusted Partial Sums (RAPS) method. Consistency testing of data was performed for rainfall data from the rain stations of Temindung, Lempake, Pampang, Sei Siring, and Tanah Merah. The results of consistency testing for the data showed that the rainfall data are consistent.

\subsection{Statistical Testing of Rainfall Data}

The rainfall data that had been tested for consistency cannot be fully utilized before being first examined through statistical testing. The utilized statistical tests were Stationary Testing (F-test and ttest) and Abnormality Testing with the Inlier-Outlier method [8]. Through the conducted statistical testing, it was shown that the resulting rainfall data from the four rain stations in the upstream part of Karangmumus watershed that had been corrected through consistency testing could be analyzed further (Table 1).

\subsection{Analysis of the Area of the Region of Influence with the Method of Thiessen Polygons}

The upstream part of Karangmumus watershed has an area of $320 \mathrm{~km}^{2}$ and includes four rainfall stations within it. Therefore, for this study, the method of Thiessen polygons was chosen to find out the area of influence [7]. The area of influence of each rain station would then be utilized to analyze the average regional rainfall. There are two outlets in the Karangmumus watershed, which are the outlet of Lempake Dam and the river outlet at Pasar Segiri (Figures 2 and 3). For the outlet of Lempake, four rain stations were utilized, being Sei Siring, Tanah Merah, Pampang, and Lempake stations. Meanwhile, for the outlet of Pasar Segiri, five rain stations were utilized, consisting of the above with the Temindung rain station.

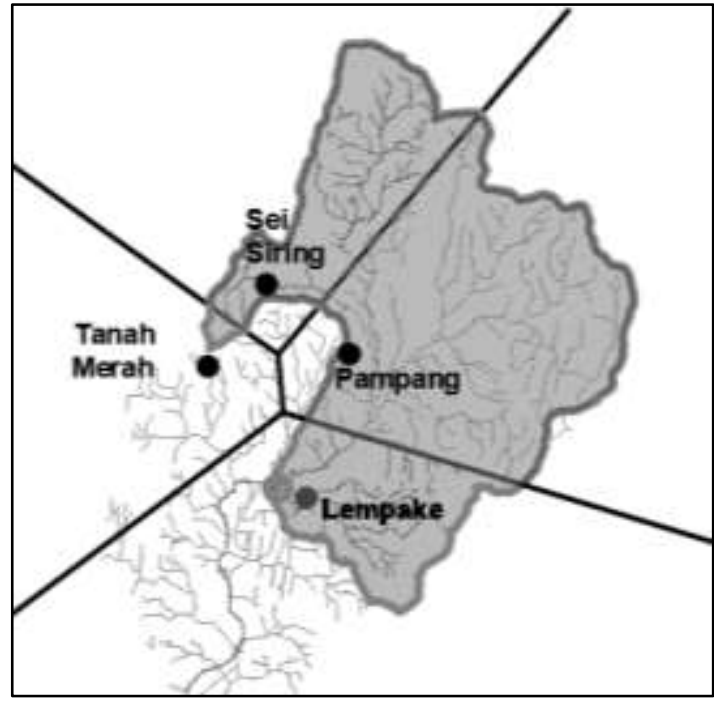

Figure 2. Thiessen Polygons for the Lempake Dam Outlet

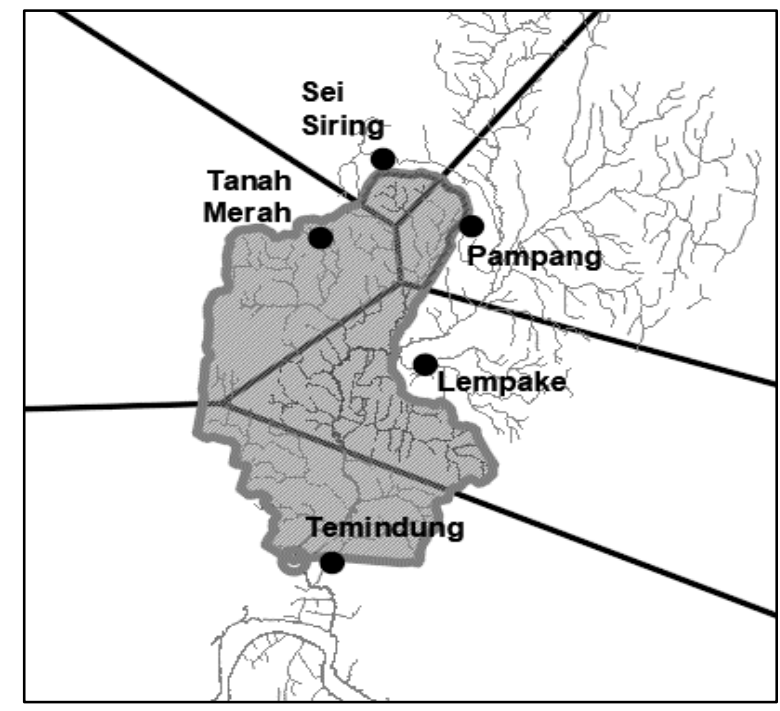

Figure 3. Thiessen Polygons for the Pasar Segiri River Outlet

\subsection{Analysis of Planned Rainfall}

Analysis of planned rainfall was conducted with usage of two statistical methods, which are the Log Pearson Type III and Gumbel Type I methods. The results of the planned rainfall that would be utilized further are the results with the lowest data skewness.

From the results of analyses of frequency and goodness of fit testing with several statistical methods to obtain the above planned rainfall, it was decided that the watershed with the Lempake Dam outlet 
utilized the results of planned rainfall from the Gumbel Type I method (skewness value -0.971). Meanwhile, the watershed with the Pasar Segiri outlet utilized the results of planned rainfall from the Log Pearson Type III method (skewness value -1.804). Tables 2 and 3 indicate the results of planned rainfall analysis for each outlet.

Table 1. Summary of Maximum Rainfall

\begin{tabular}{cccc}
\hline \multirow{2}{*}{ No. } & \multirow{2}{*}{ Year } & \multicolumn{2}{c}{ Max Rainfall $(\mathrm{mm})$} \\
\cline { 3 - 4 } & & Lempake Dam & Pasar Segiri \\
\hline 1 & 2019 & 72.88 & 88.00 \\
\hline 2 & 2018 & 56.74 & 65.72 \\
\hline 3 & 2017 & 60.29 & 46.47 \\
\hline 4 & 2016 & 54.88 & 46.75 \\
\hline 5 & 2015 & 54.40 & 23.70 \\
\hline 6 & 2014 & 55.40 & 50.17 \\
\hline 7 & 2013 & 85.12 & 51.40 \\
\hline 8 & 2012 & 68.46 & 45.09 \\
\hline 9 & 2011 & 85.42 & 55.60 \\
\hline 10 & 2010 & 78.72 & 40.42 \\
\hline 11 & 2009 & 79.13 & 54.65 \\
\hline 12 & 2008 & 80.22 & 60.22 \\
\hline 13 & 2007 & 79.16 & 75.43 \\
\hline 14 & 2006 & 75.85 & 91.14 \\
\hline 15 & 2005 & 72.34 & 107.20 \\
\hline 16 & 2004 & 74.18 & 79.71 \\
\hline 17 & 2003 & 72.63 & 34.31 \\
\hline 18 & 2002 & 71.74 & 29.97 \\
\hline 19 & 2001 & 83.14 & 49.65 \\
\hline 20 & 2000 & 84.56 & 85.43 \\
\hline & & & \\
\hline
\end{tabular}

Table 2. Planned Rainfall with the Gumbel Type I Method for the Watershed with the Lempake

Dam Outlet

\begin{tabular}{cccc}
\hline No & $\begin{array}{c}\text { Tr } \\
\text { (year) }\end{array}$ & $\begin{array}{c}\text { Chance } \\
(\%)\end{array}$ & $\begin{array}{c}\text { Planned } \\
\text { Rainfall } \\
(\mathbf{m m} / \text { day })\end{array}$ \\
\hline 1 & 1.01 & 99.00 & 16.04 \\
\hline 2 & 2 & 50.00 & 55.76 \\
\hline 3 & 5 & 20.00 & 79.53 \\
\hline 4 & 10 & 10.00 & 95.26 \\
\hline 5 & 25 & 4.00 & 115.15 \\
\hline 6 & 50 & 2.00 & 129.90 \\
\hline 7 & 100 & 1.00 & 144.54 \\
\hline 8 & 200 & 0.50 & 159.13 \\
\hline 9 & 500 & 0.20 & 178.38 \\
\hline 10 & 1000 & 0.10 & 192.93 \\
\hline
\end{tabular}

Table 3. Planned Rainfall with the Gumbel Type I Method for the Watershed with the Pasar Segiri Outlet

\begin{tabular}{cccc}
\hline No & $\begin{array}{c}\text { Tr } \\
(\text { year })\end{array}$ & $\begin{array}{c}\text { Chance } \\
(\%)\end{array}$ & $\begin{array}{c}\text { Planned } \\
\text { Rainfall } \\
(\mathbf{m m} / \text { day })\end{array}$ \\
\hline 1 & 1.0101 & 99.00 & 20.52 \\
\hline 2 & 2 & 50.00 & 56.05 \\
\hline 3 & 5 & 20.00 & 76.84 \\
\hline 4 & 10 & 10.00 & 89.72 \\
\hline 5 & 25 & 4.00 & 105.09 \\
\hline 6 & 50 & 2.00 & 115.97 \\
\hline 7 & 100 & 1.00 & 126.34 \\
\hline 8 & 200 & 0.50 & 136.37 \\
\hline 9 & 500 & 0.20 & 152.82 \\
\hline 10 & 1000 & 0.10 & 158.74 \\
\hline
\end{tabular}




\subsection{Hydrograph of the Planned Flood Discharge}

Analysis of the planned discharge in this study was conducted with usage of rain distribution by hours on the length of 6 hours. The utilized rain distribution by hours was by the PSA-007 Method. After conducting synthetic unit hydrograph analysis by the Nakayasu method, values of planned flood discharge for various return periods were obtained, which are shown in Table 4 that follows. The results of analysis of the planned flood discharge showed that the planned flood discharge for each outlet had varying values, but the flood discharge value for a return period of 1000 years had almost the same value for both outlets (being $709.49 \mathrm{~m}^{3} / \mathrm{sec}$ and $705.04 \mathrm{~m}^{3} / \mathrm{sec}$ ).

Table 4. Summary of Planned Discharge of a Watershed with Two Outlets

\begin{tabular}{ccc}
\hline \multicolumn{3}{c}{ Flood Discharge $\left(\mathbf{m}^{3} / \mathbf{s e c}\right)$} \\
\hline $\begin{array}{c}\text { Return } \\
\text { Period }\end{array}$ & $\begin{array}{c}\text { Lempake } \\
\text { Dam Outlet }\end{array}$ & $\begin{array}{c}\text { Pasar Segiri } \\
\text { Outlet }\end{array}$ \\
\hline Q 1.01 yr. & 227.40 & 63.21 \\
\hline Q 2 yr. & 329.26 & 211.52 \\
\hline Q 5 yr. & 394.92 & 309.35 \\
\hline Q 10 yr. & 438.54 & 371.58 \\
\hline Q 25 yr. & 493.67 & 445.86 \\
\hline Q 50 yr. & 534.56 & 498.40 \\
\hline Q 100 yr. & 575.15 & 548.52 \\
\hline Q 200 yr. & 615.59 & 596.98 \\
\hline Q 500 yr. & 669.03 & 676.47 \\
\hline Q1000 yr. & 709.49 & 705.04 \\
\hline
\end{tabular}

Table 5. Reservoir Containment of Lempake Dam in 2013 and 2018

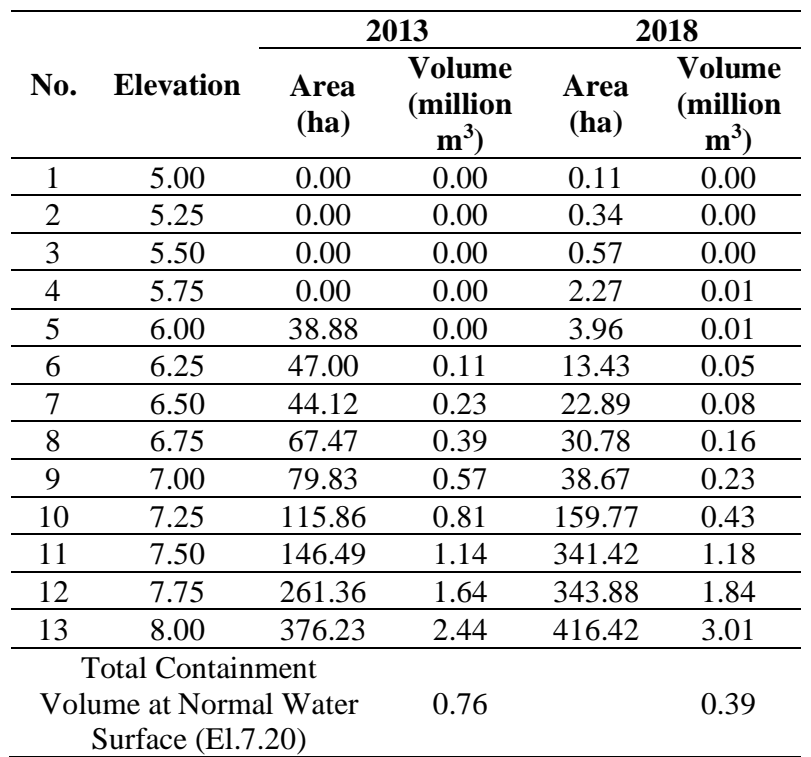

\subsection{Analysis of Reservoir Containment}

The amount of reservoir containment as utilized in this study was taken from the results of the analysis of bathymetry data that had been performed in the years of 2013 and 2018, and had been processed in Surface Volume (3D Analyst) in the ArcGIS software (Table 5). The results of analysis of reservoir containment indicated that the volume of reservoir containment at the water surface elevation in normal conditions experienced a decrease from 2013 to 2018, from a containment volume of 0.76 million $\mathrm{m}^{3}$ in 2013 to 0.39 million $\mathrm{m}^{3}$ in 2018 .

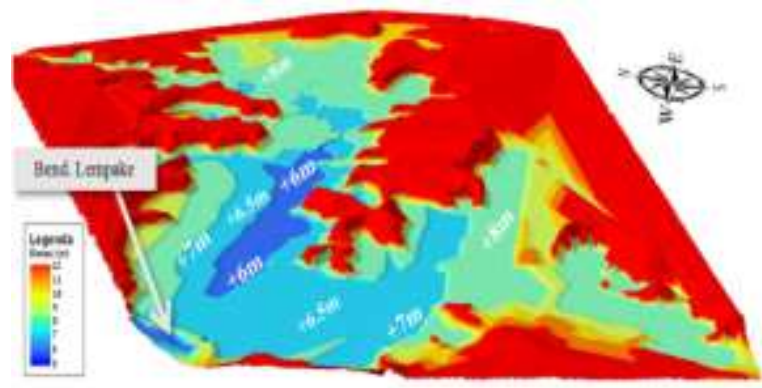

Figure 4. 3D Raster Visualization of the Bottom of the Containing Reservoir of Lempake Dam in 2013

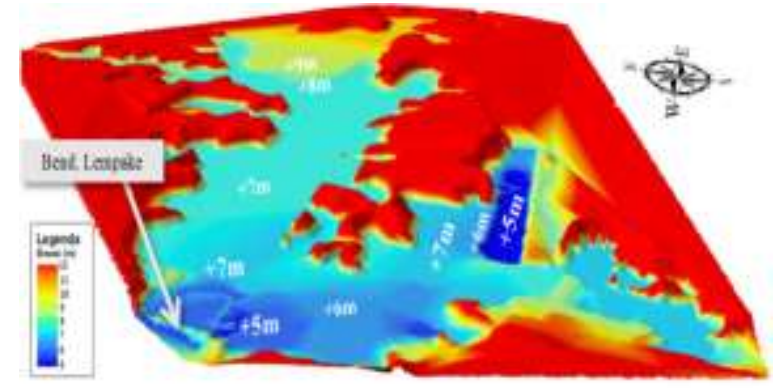

Figure 5. 3D Raster Visualization of the Bottom of the Containing Reservoir of Lempake Dam in 2018 
Based on the base elevation of the containment, from the bathymetry data, interpolation was performed with usage of the geo-statistics feature found in the ArcGIS software, for which the results were transformed into raster form (Figures 4 and 5). The results of analysis and visualization of raster data illustrated the change in the base elevation of the bottom of the containing reservoir, which in turn indicated a change in reservoir containment volume within the period from 2013 to 2018.

Changes in the cross-section of the reservoir that occurred within the period of the data indicated that sedimentation had occurred. Then, the raster data was utilized as a reference for estimating the distribution pattern of sedimentation in order to be able to obtain the containment volume in 2020, as in the following.

Table 6. Reservoir Containment of Lempake

Dam in 2020

\begin{tabular}{cccc}
\hline No. & Elevation & Area (ha) & $\begin{array}{c}\text { Volume } \\
\left(\text { million } \mathbf{~ m}^{\mathbf{3}}\right)\end{array}$ \\
\hline 1 & 5.00 & 0.00 & 0.00 \\
\hline 2 & 5.25 & 0.00 & 0.00 \\
\hline 3 & 5.50 & 0.00 & 0.00 \\
\hline 4 & 5.75 & 2.94 & 0.01 \\
\hline 5 & 6.00 & 5.04 & 0.01 \\
\hline 6 & 6.25 & 6.39 & 0.02 \\
\hline 7 & 6.50 & 6.66 & 0.02 \\
\hline 8 & 6.75 & 17.75 & 0.06 \\
\hline 9 & 7.00 & 24.36 & 0.09 \\
\hline 10 & 7.25 & 67.73 & 0.28 \\
\hline 11 & 7.50 & 341.72 & 1.20 \\
\hline 12 & 7.75 & 368.50 & 2.24 \\
\hline 13 & 8.00 & 376.23 & 3.24 \\
\hline Total Containment Volume at & 0.24 \\
\hline Normal Water Surface (El.7.20)
\end{tabular}

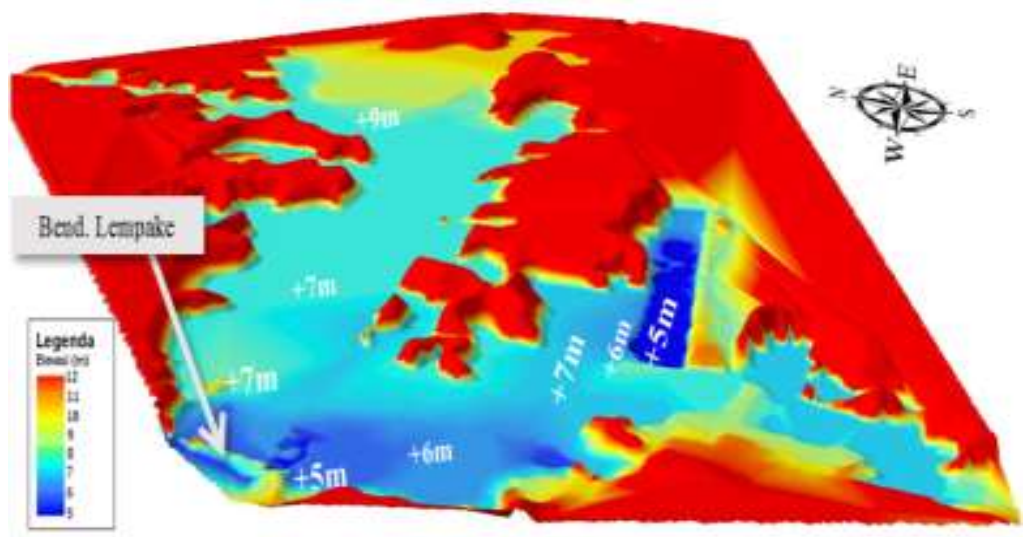

Figure 6. 3D Raster Visualization of the Bottom of the Containing Reservoir of Lempake Dam in 2020

The containment capacity of Lempake Dam in 2013 and 2018 experienced changes in that in 2013 the containment capacity was 0.762 million $\mathrm{m}^{3}$ at normal water surface elevation and in 2018 decreased to 0.390 million $\mathrm{m}^{3}$ at normal water surface elevation. The reduction in containment volume, which 
amounts to $0.372 \mathrm{~m}^{3}$, is assumed to be due to sediments that have settled over a period of five years. Therefore, the containment volume in 2020 can be predicted to be 0.241 million $\mathrm{m}^{3}$ with an annual rate of sedimentation of 0.074 million $\mathrm{m}^{3}$.

\subsection{Flood Routing}

Flood routing was performed with two primary scenarios that utilize the function of operations during the rainy season with the water level reduced to the lowest elevation.

- Scenario $1=$ Flood routing with the condition of the dam water level being full, at Full Supply Level (FSL) (El. +7.20)

- Scenario 2 = Flood routing with the condition of the dam water level being at the minimum operation level (El. +6.00$)$ or $1.70 \mathrm{~m}$ below the elevation of the edge of the spillway.

Flood routing for both of the two scenarios involve flood routing at the Lempake Dam spillway, flood routing through the river downstream of the dam, and flood routing at Pasar Segiri. Flood routing at Pasar Segiri was conducted with the input discharge as the hydrograph discharge of the flood outflow from Lempake Dam that has been routed for the upstream part of the river, to which is added the discharge from the flood hydrograph in the remaining basin for which the watershed outlet is at Pasar Segiri.

Table 7. Summary of the Water Level Height for Each Flood Return Period at Pasar Segiri (Scenario 1)

\begin{tabular}{ccccccc}
\hline No & $\begin{array}{c}\text { Return } \\
\text { Period }\end{array}$ & $\begin{array}{c}\text { Flood } \\
\text { Discharge }\end{array}$ & H & $\begin{array}{c}\text { Water } \\
\text { Surface } \\
\text { Elev. }\end{array}$ & $\begin{array}{c}\text { Safe Elev. } \\
\text { Limit for } \\
\text { Pasar Segiri }\end{array}$ & Remarks \\
\cline { 2 - 6 } & (years) & $\left(\mathrm{m}^{3} / \mathrm{sec}\right)$ & $(\mathrm{m})$ & $(\mathrm{m})$ & $(\mathrm{m})$ & \\
\hline 1 & Q 1.01 yr. & 93.15 & 3.0048 & +2.8313 & +3.30 & Safe \\
\hline 2 & Q 2 yr. & 222.14 & 3.2795 & +3.1060 & +3.30 & Safe \\
\hline 3 & Q 5 yr. & 320.48 & 3.4889 & +3.3154 & +3.30 & Over Capacity \\
\hline 4 & Q 10 yr. & 383.06 & 3.7197 & +3.5462 & +3.30 & Over Capacity \\
\hline 5 & Q 25 yr. & 457.81 & 4.0072 & +3.8337 & +3.30 & Over Capacity \\
\hline 6 & Q 50 yr. & 510.72 & 4.2504 & +4.0769 & +3.30 & Over Capacity \\
\hline
\end{tabular}

From the results of calculations above, it can be concluded that the capacity of the river cross-section at Pasar Segiri is not sufficient for a flood discharge that occurs with a return period of greater than 2 years if the flood occurs while the surface water level in the containing reservoir is at the peak elevation or is full.

Table 8. Summary of the Water Level Height for Each Flood Return Period at Pasar Segiri (Scenario 2)

\begin{tabular}{ccccccc}
\hline No & $\begin{array}{c}\text { Return } \\
\text { Period }\end{array}$ & $\begin{array}{c}\text { Flood } \\
\text { Discharge }\end{array}$ & $\mathrm{H}$ & $\begin{array}{c}\text { Water } \\
\text { Surface } \\
\text { Elev. }\end{array}$ & $\begin{array}{c}\text { Safe Elev. } \\
\text { Limit for Pasar } \\
\text { Segiri }\end{array}$ & Remarks \\
\cline { 2 - 6 } & (years) & $\left(\mathrm{m}^{3} / \mathrm{sec}\right)$ & $(\mathrm{m})$ & $(\mathrm{m})$ & $(\mathrm{m})$ & \\
\hline 1 & Q 1.01 yr. & 93.15 & 2.7439 & +2.5704 & +3.30 & Safe \\
\hline 2 & Q 2 yr. & 211.54 & 3.2569 & +3.0834 & +3.30 & Safe \\
\hline 3 & Q 5 yr. & 309.51 & 3.4656 & +3.2921 & +3.30 & Safe \\
\hline 4 & Q 10 yr. & 371.76 & 3.6764 & +3.5029 & +3.30 & Over Capacity \\
\hline 5 & Q 25 yr. & 446.05 & 3.9610 & +3.7875 & +3.30 & Over Capacity \\
\hline 6 & Q 50 yr. & 498.61 & 4.1947 & +4.0212 & +3.30 & Over Capacity \\
\hline
\end{tabular}

From the results of calculations above (Tables 7 and 8), it can be concluded that the capacity of the river cross-section at Pasar Segiri is not sufficient for a flood discharge that occurs with a return period 
of greater than 5 years if the flood occurs while the surface water level in the containing reservoir is at the peak elevation or is full.

Table 9. Summary of the Comparison of the Flood Reduction Capability of Lempake Dam

\begin{tabular}{cccc}
\hline \multirow{2}{*}{ No. } & Return Period & \multicolumn{2}{c}{ Flood Reduction (\%) } \\
\cline { 2 - 4 } & (years) & Scenario 1 & Scenario 2 \\
\hline 1 & Q 1.01 yr. & $67.0 \%$ & $78.4 \%$ \\
\hline 2 & Q 2 yr. & $65.8 \%$ & $74.6 \%$ \\
\hline 3 & Q 5 yr. & $64.7 \%$ & $72.2 \%$ \\
\hline 4 & Q 10 yr. & $64.0 \%$ & $71.2 \%$ \\
\hline 5 & Q 25 yr. & $63.3 \%$ & $69.9 \%$ \\
\hline 6 & Q 50 yr. & $62.8 \%$ & $69.2 \%$ \\
\hline
\end{tabular}

\subsection{Mapping of Flood Inundation}

Mapping of flood inundation was performed through RAS Mapping with the HEC-RAS software. The resulting inundation was then overlaid on aerial photography. The input from the inundation mapping for HEC-RAS utilized hydrograph data from the results of flood hydrograph analysis for Lempake Dam with return periods of 2 and 5 years. Meanwhile, the geometry input utilized in this analysis perused Digital Elevation Model (DEM) data as the results of generating data on the river crosssection in the remaining basin up to Pasar Segiri.

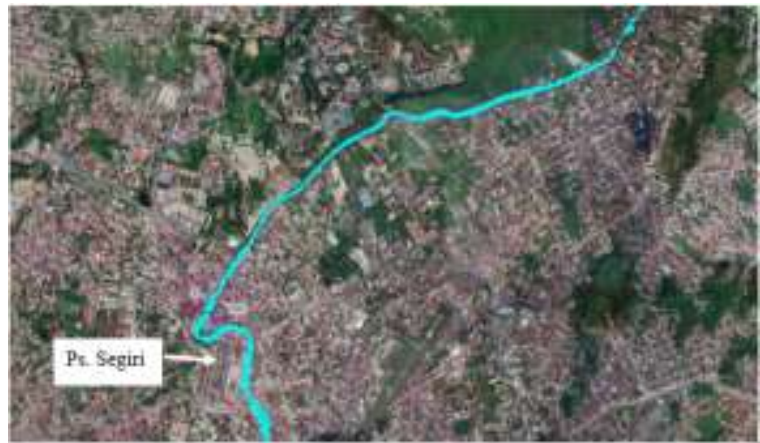

Figure 7. Mapping of Flood Inundation at Pasar Segiri with a Return Period of 2 Years (Scenario 1)

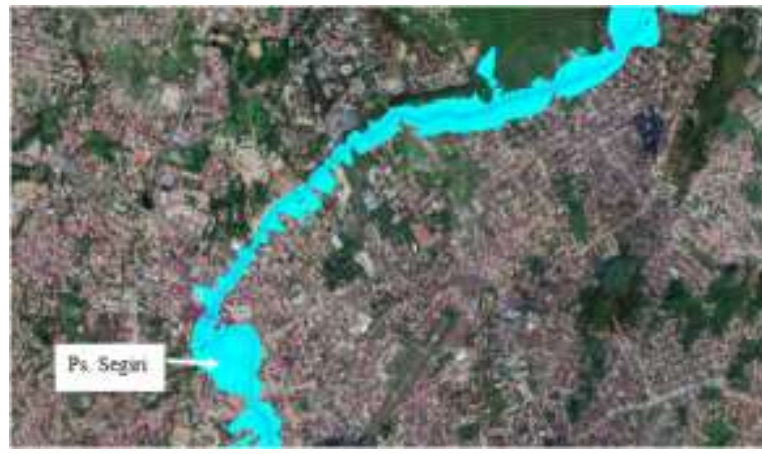

Figure 9. Mapping of Flood Inundation at Pasar Segiri with a Return Period of 5 Years (Scenario 1)

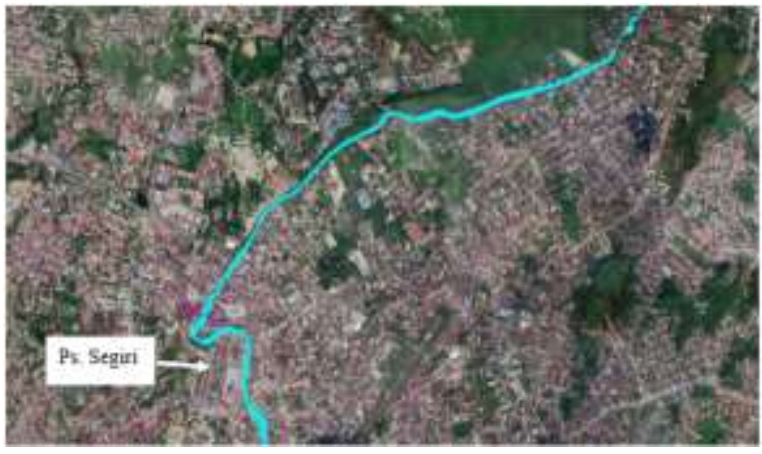

Figure 8. Mapping of Flood Inundation at Pasar Segiri with a Return Period of 2 Years (Scenario 2)

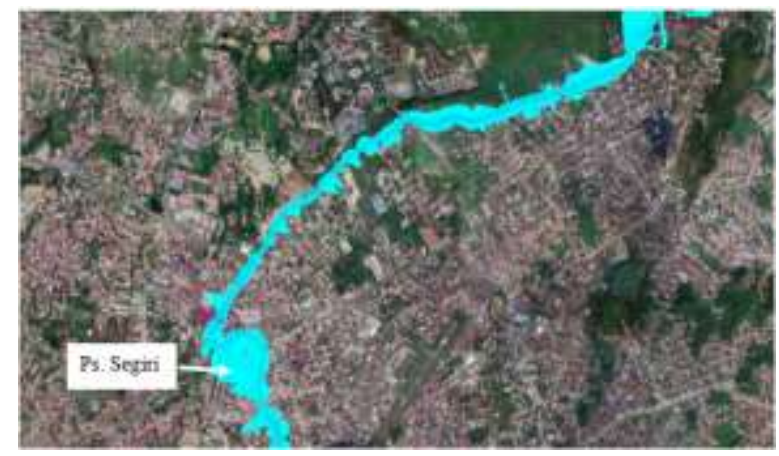

Figure 10. Mapping of Flood Inundation at Pasar Segiri with a Return Period of 5 Years (Scenario 2) 
From the results of the flood inundation mapping in the area of Pasar Segiri, it can be concluded that the flood with a return period of 2 years does not exceed the river capacity, in accordance with previous calculations (Figures 7 and 8). In the area of Pasar Segiri, flood inundation occurred with a return period of 5 years. From the results of flood inundation mapping above, it can be seen that the inundation in Scenario 2 is less than the inundation in Scenario 1 (Figures 9 and 10).

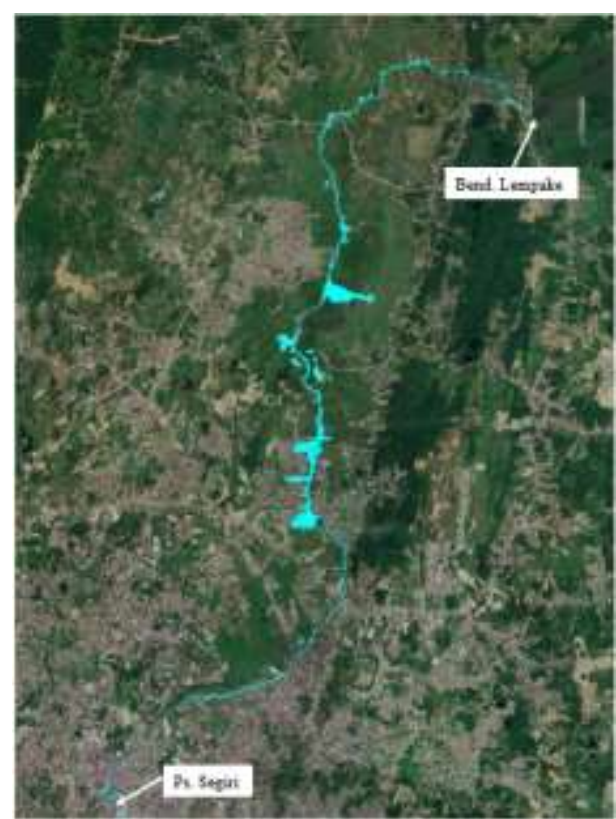

Figure 11. Mapping of Flood Inundation in the Remaining Basin with a Return Period of 2 Years (Scenario 1)

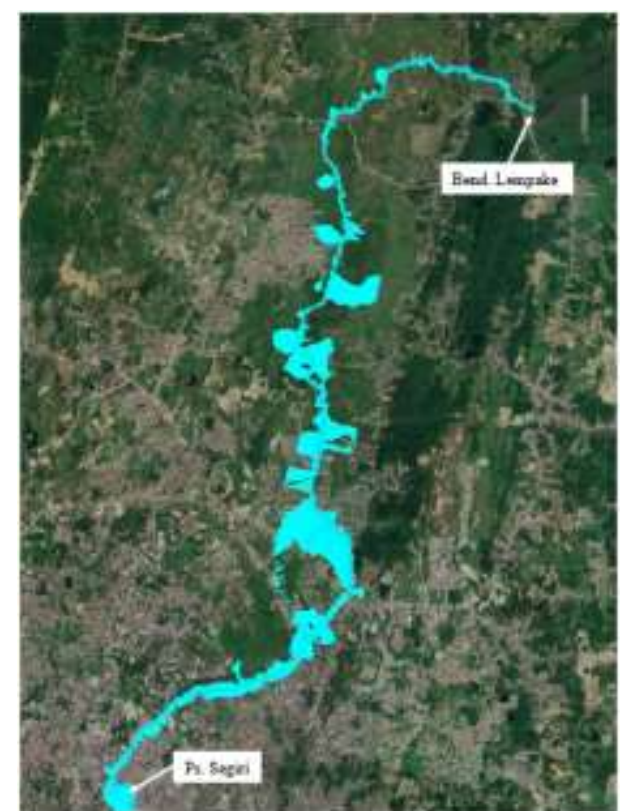

Figure 13. Mapping of Flood Inundation in the Remaining Basin with a Return Period of 5 Years (Scenario 1)

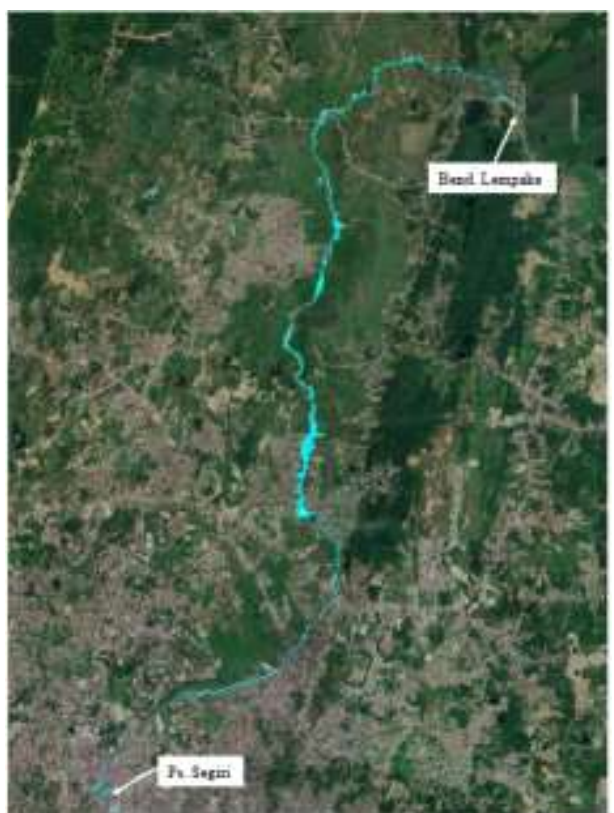

Figure 12. Mapping of Flood Inundation in the Remaining Basin with a Return Period of 2 Years (Scenario 2)

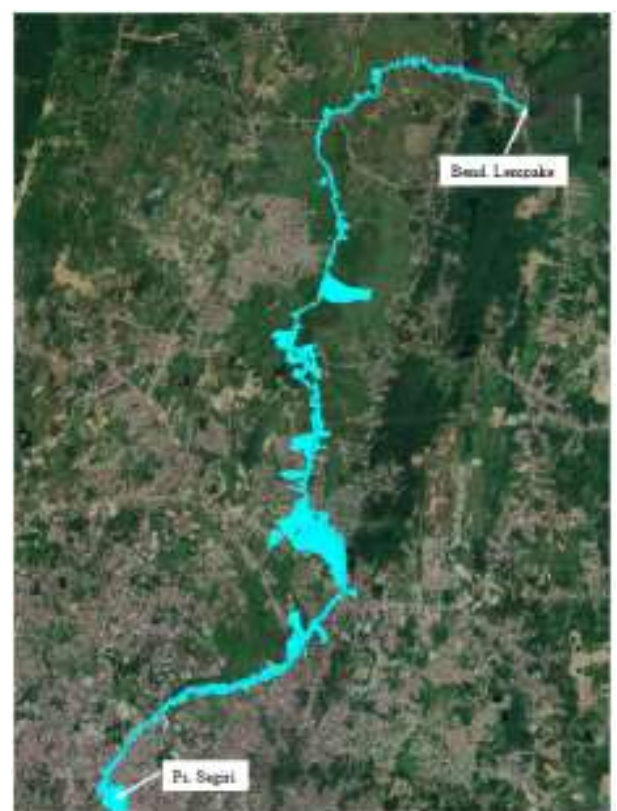

Figure 14. Mapping of Flood Inundation in the Remaining Basin with a Return Period of 5 Years (Scenario 2) 
In the area of the river in the remaining basin, flood inundation occurred starting with a return period of 2 years for Scenarios 1 and 2. However, the inundation that occurred was not present in the area of settlements or public facilities (Figures 11 and 12).

In the mapping of flood inundation for a return period of 5 years in the remaining basin, the inundation that occurred can be seen to be present in settlements and public facilities, in both Scenario 1 and Scenario 2 (Figures 13 and 14).

\section{Conclusion}

From the bathymetry data that was developed in Surface Volume (3D Analyst) in ArcGIS, the containment capacity of Lempake Reservoir in 2013 and 2018 experienced changes from 0.762 million $\mathrm{m}^{3}$ to 0.390 million $\mathrm{m}^{3}$ at the elevation of normal water surface level. The reduction in containment volume is the amount of $0.372 \mathrm{~m}^{3}$, which is assumed to be by sediments that have settled over a period of five years. Thusly, the containment volume in 2020 can be predicted to be 0.241 million $\mathrm{m}^{3}$. The flood discharges at Pasar Segiri are $\mathrm{Q}_{1.01 \mathrm{yr}}=93.15 \mathrm{~m}^{3} / \mathrm{sec} ; \mathrm{Q}_{2 \mathrm{yr}}=222.14 \mathrm{~m}^{3} / \mathrm{sec} ; \mathrm{Q}_{5 \mathrm{yr}}=320.484 \mathrm{~m}^{3} / \mathrm{sec}$; $\mathrm{Q}_{10 \mathrm{yr}}=383.06 \mathrm{~m}^{3} / \mathrm{sec} ; \mathrm{Q}_{25 \mathrm{yr}}=457.81 \mathrm{~m}^{3} / \mathrm{sec}$; and $\mathrm{Q}_{50 \mathrm{yr}}=510.72 \mathrm{~m}^{3} / \mathrm{sec}$. The capacity of the river crosssection at Pasar Segiri is not sufficient for a flood discharge that occurs with return periods of greater than 2 years for scenario 1 and return periods of greater than 5 years for scenario 2 . The scenario with maintenance of the water surface condition at the minimum operation level (El. +6.00$)$ or $1.70 \mathrm{~m}$ below the elevation of the edge of the spillway of Lempake Dam is the most optimal scenario for the function of flood control in the upstream area.

Based on the results of analysis that had been performed, some suggestions can be made in relation to the effort to control floods or outflows, one of which is by improving the condition of land usage and maintaining the condition of the upstream part of the river to retain vegetation. Another effort is to conduct efforts of coordinating reservoir operations to anticipate the floods that occur during the rainy season. There needs to be a structure to control sediments and a dam to reduce the flood discharge that enters the Karangmumus River.

\section{References}

[1] Brunner, G.W. (2016) HEC-RAS River Analysis System. 2D Modeling User's Manual. USA: US Army Corps of Engineers.

[2] Childs, Colin. (2004). Interpolating Surfaces in ArcGIS Spatial Analyst. USA: ESRI Education Services.

[3] I Made Kamiana. (2011). Teknik Perhitungan Debit Rencana Bangunan Air [Techniques of Calculating the Planned Discharge of Water Structures]. Yogyakarta: Graha Ilmu.

[4] Limantara, Lily Montarcih. (2010). Hidrologi Praktis [Practical Hydrology]. Bandung: Lubuk Agung.

[5] Ministry of Public Works and Public Housing, Directorate-General of Water Units, Working Unit for Dam Authority. (2017). Petunjuk Teknis Perhitungan Debit Banjir Pada Bendungan [Technical Guidance of the Calculation of Flood Discharge for Dams]. Jakarta: Kementerian Pekerjaan Umum dan Perumahan Rakyat.

[6] PT. Catur Bina Guna Persada. (2018). Laporan Akhir Inspeksi Besar Bendungan Lempake Kota Samarinda [Final Report of the Major Inspection of Lempake Dam, City of Samarinda] (Contract No. HK.02.03/SATKER.OP.SDA.K.III/OP/SDA.I/243.C/XII/2017 on the date of December 22, 2017).

[7] Soemarto, CD. (1987). Hidrologi Teknik [Hydrological Engineering]. Surabaya: Usaha Nasional.

[8] Soewarno. (1995). Hidrologi Aplikasi Metode Statistik untuk Analisis Data [Hydrology: Applications of Statistical Methods for Data Analysis]. Bandung: Nova.

[9] Sosrodarsono, Suyono and Takeda Kensaku. (2003). Hidrologi Untuk Pengairan [Hydrology for Water Resources. Jakarta: PT. Pradnya Paramita. 
[10] Suhartanto, E., Haribowo, R. (2011). Application of Kagan-Rodda method for rain station density in Barito Basin Area of South Kalimantan, Indonesia. Journal of Applied Technology in Environmental Sanitation 1 (4).

[11] Wardani, Y., Suhartanto, E., Haribowo, R. (2019). Analysis of The Correlation Between Land Use Changes in Sub Watershed Wuno Toward Lifetime of Wuno Reservoir, Sigi District, Central Sulawesi Province. Civil and Environmental Science Journal 2 (1), 1-14. DOI: https://doi.org/10.21776/ub.civense.2019.00101. 